\title{
Neoliberalism, Digital Communication Technologies and the Cultural and Creative Industries
}

\author{
Kelechi Chijioke Samuel \\ School of Media Communication, Pan-Atlantic University \\ *Corresponding author email: kelechi_nwagbara@yahoo.com
}

Received: 04 September 2019 / Revised: 13 October 2019 / Accepted: 23 October 2019 / Published: 24 October 2019

\begin{abstract}
This article examines the use of internet-based media platforms for marketing communication among fashion designers as a manifestation of globalization and neoliberal free trade. It highlights some features of neoliberalism, sub-themes of the cultural and creative industries concept, and some impact of using digital media technologies, and argues that there is nexus between these three concepts. It notes that neoliberal globalization has promoted free markets and facilitated the disannulment of barriers which previously excluded many from trading freely. The findings suggest there are inherent economic benefits as well as precarious conditions associated with the use of digital marketing platforms. These conditions, some of which subvert the individuals' rewards from using their talent, are consistent with the rise of precarious work under neoliberal capitalism. It recommends that cultural producers should seek ways of maximizing the benefits in using these media platforms while minimizing the burdens and precarious conditions.
\end{abstract}

Keywords: Neoliberalism, digital technologies, cultural and creative industries, intellectual property.

\section{Introduction}

The cultural and creative industries (CCI) concept has largely been an economic and political policy success in most countries where it has been launched. It has created economic empowerment for ordinary citizens by encouraging the exploitation of individual talent, creativity, and contributed significantly to mainstream economic growth and expansion in ways not previous accounted for. Yet, there remains, on the ground, some serious disquiet about the real economic conditions of CCI workers, despite the seeming political success of the concept. Banks and O'Connor (2009) among other writers (McRobbie, 2002; Nielsen and Rossiter, 2005; Gill and Pratt, 2008; Oakley, 2009; Gill, 2010; Florida, 2012; Cohen, 2012; and de Peuter, 2014 have highlighted some of these concerns about work precarity in the CCI. Specifically, de Peuter (2014) noted that these concerns seem to be manifestations of capitalist exploitations of labour under postFordism. In other words, de Peuter implicates neoliberal capitalism in the observed precarity of work in the CCI.

Some writers (Abbasi, Vassilopoulou and Stergioulas, 2017; Li, 2018; and others) have observed that digitization and globalization have engendered creative production in the CCI. That is, digital information communication technologies (DICTs) have introduced new forms of creative employment and occupations, new work processes, new art genres, producer-customer relations, granted access to new markets, and generally transformed economic structures for good. Yet, despite these economic benefits, many of these digital technologies are thought to be associated with the rise of precarious work conditions in many CCI segments. Gill and Pratt (2008) have argued that the world wide web and the internet may be connected with the growth of precarious conditions of work across various economic segments.

This is largely because work and global trade are increasingly dependent on, and are being reconfigured by growing digitization, internet-driven communication and financial intermediation. More than any other 
factor, digital communication is facilitating the growth of globalization through the deregulation of labour relations, deconstruction of labour markets, flexibilization of labour, and the responsibilization of workrelated risks. Terranova (2000) observed that the growth of the internet has led to increased flexibility of labour and the growth of precarious work practices such as supplementing (taking work home after official working hours). These are all hallmarks of work under neoliberal capitalism and are frequently observed work practices among creative workers.

Part of what has also emerged in literature is the challenge that digital technologies and globalization pose to the typical small and medium-scale producers who predominantly constitute the CCI. Indeed, the digital revolution has given small producers access to local and global markets. But it has also led to the globalization of local markets by giving large global players access to local markets. The question is, who enjoys more economic advantage in this new world of access to markets? The small producers or the global players? This question has led to some concerns about the effects of globalization on cultural and creative productions.

If one examines the effects of neoliberal globalization across the world and compares them with the effects of the use of digital technologies by CCI workers, it appears like the goals of neoliberalism and globalization, and the effects of digital technologies on CCI productions are converging. Shultz (2011, p.19) noted, for instance, that, in the United States, the creative industries are associated with neoliberal urban development agendas. Also, Cohn (2013) noted, digital recommendation systems used by large online companies like Amazon, Google, etc. are subtly and insidiously promoting capitalist consumerism. But this relationship between neoliberalism and the CCI is however not new. Adorno and Horkheimer raised these concerns in the mid-1940s.

Using the fashion designing segment of the CCI as its focus, this article explores the growing interconnectedness between neoliberalism, digital information communication technologies (DICTs), and the CCI. The objective is to highlight the economic benefits of the CCI concept, establish how DICTs engender the growth of the CCI in the context of globalization, and underscore the precarious work conditions that attend CCI work as a result of the pervasive use of DICTs in a new world driven by neoliberal capitalism and globalism. It is hoped that this will enable cultural and creative workers understand and guard against the negative and precarious effects of digital communication technologies and globalization, while maximizing the benefits and opportunities they provide.

\section{Origins, Evolution and Definition of the CCI Concept}

The concept and theoretical foundations of the term cultural industries has its roots in Critical Theory. Adorno and Horkheimer, writing on what they termed 'Culture Industry', as early as the 1940s, essentially introduced the concept and discourse to academic literature. This claim is made by Theodor Adorno himself and corroborated by other writers like Lee (2013). Since then, many ideological levels of discourse have emerged around culture and industry. Adorno and Horkheimer (1947) argued about the culture industry from a Marxist perspective during the era of industrialization and mass production. Or what some have termed Fordism - the mass production of identical and standardized products.

This was also the very early years of television as a mass medium. Adorno and Horkheimer (1947) argued that culture was being exploited by capitalism through mass media content and the mass production of goods and services. For them, the culture industry was another conduit for the spread of capitalist consumerism. By extension, therefore, capitalism was being entrenched in the psyche of the population, and television and broadcast media were tools of control by the state and powerful interests from the ruling class. Adorno and Horkheimer's thoughts and arguments on the 'culture industry' seemed to have been laced with a dose of cynicism and Marxists' criticism of capitalism. In their view, there was hardly a positive side to the commodification of culture as valuable goods and services for society's consumption and enjoyment.

For Adorno and Horkheimer, the culture industry, which included television and mass media, was therefore 'a crucial ideological site of academic interest' (Lee, 2013, p. 2) because it provided a means by which 
capitalist ideologies were thriving in the society. Adorno and Horkheimer, argued that the 'culture industry' was a capitalist tool of economic exploitation of consumers, and saw the culture industry as capitalism's captured space. However, since their writings, many scholars have critiqued and re-evaluated Adorno and Horkheimer's contributions to the culture industry debate. Unlike Adorno and Horkheimer, I will rather argue that the culture industry is contested space where competing ideologies contest for relevance. This is because the fragmented structure of the culture industry is such that affords even marginal players and ideologies in society a chance to have their say amid dominant players and ideologies.

German scholar, Jurgen Habermas, supports this view that the culture industry presents sites for the contestation of ideologies. Habermas (1989) argued that the culture industry plays a central role in the constitution of the 'public sphere', where they act as mediums for the peddling and transmission of ideological values. Habermas' view of the culture industry reflects in contemporary discourse on cultural industries which positions them as avenues for the expression of individual talent and creativity, platforms for cultural participation and pathways to economic prosperity. The outputs from these individual talents and creativity take the form of products and services which compete for acceptance in the marketplace and ultimately gain relevance in the society. The cultural industries thus, present avenues for the exchange and diffusion of ideas and cultures.

Hesmondhalgh (2002, p.6) arguing along this same line, stated that the cultural industries are 'agents of economic, social and cultural change'. This means that they constitute means for the production and distribution of goods and services that transmit dominant and even marginal social ideologies, values and cultures. Leveraging various mass media and other avenues for human interaction, the cultural industries foster the emergence of dominant cultures, and on a global scale, they promote the globalization of cultures. The globalization of cultures can be seen in the products and services we consume in everyday life - clothes we wear, media content we consume, houses we live in, etc.

From the mid-1940s when Adorno and Horkheimer wrote up till now, a lot has really changed. It is important to note that there has been a shift in the site of the battle for the ideological and economic control of culture and cultural productions. Whilst in the former times television and other forms of the traditional mass media were the center of the battles, in the digital age, the internet and other internet-based digital information communication technologies (DICTs) now constitute a crucial site of battle for social, economic and ideological interests. This is because the internet and internet based DICTs are constituting large virtual communities of people engaged daily by various content producers on the internet.

The internet also now constitutes a site for commerce. With digitization and the growth of financial technologies, the internet is now playing a major role in everyday commerce and the consumption of various products and services. This is why almost every cultural and creative producer is seeking to leverage internet-based platforms for marketing and distribution of their creative outputs. Fashion designers, writers, musicians, comedians and other performing artists, architects and landscape designers, retailers (large and small), advertisers, sundry art and craft producers, and other producers of everyday lifestyle products and services are all struggling for space and relevance on the internet.

From this perspective of the everydayness of the cultural industries, many contemporary definitions of the cultural industries have emerged. However, in most cases, the overriding factor in the definitions is the recognition that individual creativity from cultural activities provides a viable pathway to economic prosperity. Consequently, the central idea in the cultural industries discourse has been how to harness individual talents from everyday cultural and creative activities and position them for economic benefits within the sphere of intellectual property and the knowledge economy. This idea led to what is now known as the cultural and creative industries (CCI).

\subsection{Some definitions and criticisms of the CCI}

According to the DCMS (1998; 2001, p.4) the CCI are "those industries which have their origin in individual creativity, skill and talent, and which have a potential for wealth and job creation through the generation and exploitation of intellectual property." According to the DCMS template, the CCI include: advertising, 
architecture, arts and antique markets, crafts, design, designer fashion, film and video, interactive leisure software (electronic games), music, performing arts, publishing, software and computer services, and television and radio. In all, the DCMS identifies thirteen segments as constituting the CCI in the UK. For more definitions of the CCI concept see, Caves, 2000; Garnham, 1987; Scott, 1999; and other works on the CCI.

Critics of the CCI concept have however, noted that defining the concept has been fraught with ambiguity, as various definitions and conceptualization of the subject matter have been "inconsistent and confusing" (Galloway and Dunlop 2007, p.17). The CCI concept has evolved and remains a subject of intellectual dispute among academics and policy makers. The works of several authors and policy analysts (Garnham, 1987; Miège, 1989; Peck, 2005; Hesmondhalgh, 2007; Lovink and Rossiter, 2007; Pratt, 1999, 2005, 2008; Gill and Pratt, 2008, etc.) highlight the disputes and the academic debates about the concept. Some critics of the CCI concept have suggested that the term 'creative industries' is simply a political rebranding of the cultural industries.

In the final analysis and regardless of the shortcomings in the definitions and other issues that problematize the concept, the development of the CCI remains an economic and social policy success. The concept helped reformulate economic development policy from the traditional way of focusing on large industrial productions to acknowledging the contributions of individual and small-scale producers, and how to promote their well-being in the society. As a policy measure, the concept remains a veritable tool that promotes social inclusion in modern societies. To ensure long term sustainability of its contributions to economic development, it has been argued that enterprises producing and offering products and services in these segments should imbibe principles of modern marketing in order to maximize growth and impact. This implicates the use of digital technologies which, evidently, has reconfigured the marketing and distribution of products and services in this digital age.

\section{The Growth of Precarious Work}

Precarious work is a phenomenon that has long been the experience of workers throughout the history of capitalist production and paid employment. In a sense this formed some of the basis for the class tensions that underpins Marxist ideology. Neilson and Rossiter (2005) have noted that work precarity is the norm in neo-capitalism. Precariousness of work is now prevalent in the informal and formal sectors of economies, and in both developed and less developed countries (Schneider, 2002). Prior to this time, precarious work seemed to be more prevalent in less developed economies and less formal sectors of the economy.

Precariousness of work refers to the uncertainty, instability and insecurity of work in which employees bear more of the risks of work (as opposed to businesses or government) and receive limited social benefits and statutory entitlements (Vosko, 2010). Vosko highlights capitalist exploitation of labour in the deliberate transfer of work risk from employers to employees which leaves workers vulnerable to the whims and caprices of employers. According to Kalleberg (2009), precarious work refers to employment that is uncertain, unpredictable and risky, especially from the point of view of the worker, resulting in distress that is obvious in many ways. Precarious work creates emotional and financial insecurity and often triggers many unpleasant social outcomes such as emotional breakdowns, bankruptcy and poverty, exclusion and deprivation, crime and social unrests, etc.

Although capitalism has always been characterized by the exploitation of labour, especially lower skilled labour, what the world is experiencing in this epoch is that even very skilled, high-status urban workers in the more formal sectors of economies are increasingly being affected by precarious work (Gill and Pratt, 2008; Gill, 2010). This includes cultural and creative workers in urban societies who are now engaged in insecure, casual or intermittent employment. Neo-capitalism is gradually wiping out the standard stable employment contracts which was once the norm at the industrial workplace, especially during the economic boom that came after World War II. In its place, there are now new work arrangements that predispose workers to the uncertainties and insecurities associated with precarious work. Thus, the growth of 
precarious work has become contemporary concern in politics, the media, the creative industries, and even among university researchers (Kalleberg, 2009).

This growth in the incidence of work precarity has produced a generation of workers disproportionately affected by the risks and insecurities inherent in work, and who have very little expectation of work security (Gill and Pratt, 2008). Many writers have identified work precarity as a contemporary problem in many segments of the cultural and creative industries (Miege, 1989; McRobbie, 2002; Neilson and Rossiter, 2005; Cohen, 2012; Florida, 2012; de Peuter, 2014; etc.). This has led to the coinage of the term 'precarious generation' (Bourdieu, 1999). Vallas and Prener (2012) have noted that these precarious conditions of work represent the subtle rise of neoliberalism and the re-enactment of capitalist control and exploitation of labour.

Kalleberg and Hewison (2012) have hinted that the expansion of precarious work is associated with social, economic, political and technological changes that have occurred over the last decades of increased globalisation and neoliberalism. Kalleberg and Hewison argue that neoliberal policies have largely been a hedging strategy adopted by nation-states and corporations to manage the increased risks associated with the rapidly occurring changes in the social, technological, regulatory and economic policy environments. However, some writers have also noted that neoliberal capitalism is not the only source of the growth of precarious work. Gill and Pratt (2008) have suggested that the growth of precarious work (especially among cultural workers) may also be connected to the growth and development of the World Wide Web, and the huge expansion of productive activities within the cultural and creative industries. Scrase (2003) observed that globalization intensified and exacerbated the precarious existence of artisan communities through increasing global competition, the mass production of craft goods, and shifting trends in fashion, cultural taste and aesthetics. Local markets are now accessible to large global players with economies of scale, to the detriment of small local players. This is made possible through the internet and DICTs.

\subsection{Digital technologies and work precarity.}

Hardt and Negri (2000) have argued that there is evidence that the introduction of computer technology radically transformed work. But beyond the impact of the computer, the emergence of the internet and the various forms of digital media devices that support widespread internet use has further transformed not just work but workers themselves. Contemporary capitalism and global business is increasingly dependent on the internet and DICTs. These technologies are facilitating new forms of corporate and political governance.

New models of work, occupation, employment, work relations, and social interactivity in society and industry are emerging. The internet has led workers to modify their operations, their ways of thinking, their ways of interacting, their ways of conceptualizing new products, services and work processes. Digital devices and computer programs have enabled continuous interactivity between producers and market players in a wide range of contemporary production systems. Workers and their employers, co-workers and customers can interact across time and space without much hindrance. Literature seems to suggest that the internet and DICTs can impact precarity of work in at least two ways; i) long hours of work that can largely be categorized as free labour, immaterial labour and affective labour, and, ii) the use of digital media may expose creative works to potential losses in economic value as a result of unauthorized copying.

Terranova (2004) notes that the internet has engendered contemporary trends such as workforce flexibility and the act of bringing supplementary work home from the conventional office. Thus, the internet and DICTs continue to blur the line between work time and personal time to the extent that life itself becomes work and work becomes life. In the final analysis life becomes a pitch, as Gill (2010) asserts. It also blurs the line between production and consumption, especially of cultural goods, such that content producers easily become consumers, and consumers become producers. As the production and consumption processes become blurred, this situation produces free and unwaged labour. A situation in which work processes shift from the factory to society, and labour is de-territorialized and decentralized, so that the whole society is placed at the disposal of capitalist profits (Negri, 1989). So, in a sense, the internet is now 
constituting the social factory (Tronti, 1966), and unleashing a sophisticated global production and consumption system (Virno and Hardt, 1996; Terranova, 2004). With the internet creative workers are now able to share artistic designs and outputs with target audiences and get feedbacks on a continual basis. This means after working hours, they may keep working, in the name of customer interactions, without realizing it. Thus, Miège (1989) observed, among other things that, technological innovations have over the years, transformed artistic practice. But this is not without its unique drawbacks which may include selfexploitation and overworking.

The internet and DICTs have reconfigured markets and inspired new ways of organizing commerce in the cultural and creative economy. The reality of this digital era is that, it is not enough for cultural workers to know the skills of their art and craft. They should know how to reach, inform and engage with their market and various publics (Kotler, 1980), especially, using digital media platforms. Literature suggests that the internet provides profound platforms and opportunities for small-and-medium-scale enterprises to by-pass powerful gatekeepers in the retail marketing and distribution of products. The advent of mobile communication devices and explosion of digital social networking platforms has broken the hegemony of the one-to-many communication system of traditional mass media organizations. This has changed the dynamics of media content production, distribution and consumption form one-to-many to many-to-many (Scolari, 2009). This new many-to-many distribution model provides cost-effective alternatives to traditional mass media. These networking platforms enable creative producers stay connected with their target audiences, communities and social networks of fellow producers, suppliers and other market players in the immediate cluster and beyond. Social networks enable them share creative outputs, source material needs, outsource labour needs, etc. In summary, the internet and digital media platforms invariably improves the network sociality of the cultural and creative worker.

Internet based digital media platforms, virtual communities and networking sites house significant audiences across time, space and social demographics. With the push of a device button, a cultural producer can reach thousands and even millions of people across the world. But there is a potential problem of compromising economic rewards from IPs that may be inherent in sharing creative outputs over the internet. By sharing works on social networks, creative crafts and outputs can easily be copied and mass produced. This is without prejudice to the benefits associated with belonging to social networks. This situation presents a precarious dilemma to creative workers who may need to protect creative outputs from unauthorized copying. Yet, they also need to publicize their creativity in order to derive full economic benefits of their creative talent. Spender (2009, p.9), observed that in the digital era, being found on the internet is a strategic imperative and evidently more important than the concern of being copied. Hence, the major concern for fashion designers is less about the risk of being copied, and more about the potential of the brand being seen. For that reason, fashion designers are happy to share their works via digital media because they hope to reach many people, despite knowing that they may be copied.

Castells $(2000,2004)$ argued that as the global economy becomes more networked through the globalizing effects of the internet and digital technologies, so has labour become more precarious. Castells argues that the effects of digital technologies on work and employment has led to major transformation of work processes. And that the result is tending toward mass redundancy and the individualization of labour and flexibilization of work. Some other writers (Oakley, 2006; Gill 2007; Banks, 2007; Gill and Pratt, 2008) have also argued that as the global economy becomes more networked through the internet and digital media platforms, so has creative labour become more precarious. Just as Castells wrote earlier, these writings made a connection between digital technologies, neoliberal globalization and precarity of work.

\subsection{Drawing a Nexus between Digital Technologies, Neoliberalism and the CCI}

As a starting point, we can quickly identify the fact that the CCI concept advocates the sub-themes of: private property rights; standing on one's own feet through the deployment of individual talents and skills as a route to economic prosperity, economic empowerment, self-reliance and freeing the individual from reliance on the state or employers, among others. Harvey $(2007$, p.2) defines neoliberalism as a 'theory of 
political economic practices which proposes that human well-being can best be advanced by liberating individual entrepreneurial freedoms and skills within an institutional framework characterized by strong private property rights, free markets and free trade'. There is therefore, a lot of common ground between the core ideas of neoliberalism and some of the sub-themes of the CCI concept. Neoliberalism promotes the idea of freedom of the individual to access and participate in markets freely. While digital technologies, through the internet (social networking and e-commerce platforms), constitute and provide access, and enable individuals to freely participate in global markets. Neoliberalism promotes the philosophy of personal choice and individual rights. Digital media technologies broaden access to information and extend the scope of personal choice.

Digital information communication technologies (DICTs) facilitate the development and marketing of new products and services. Through digital technologies small scale producers in the CCI segments can access global audiences and markets without necessarily relying on powerful gatekeepers like distributors and media houses who were previously used to access markets. Digital media technologies have made it easier for disadvantaged groups and previously excluded minorities to access information and markets on a global level. Many of these disadvantaged groups are small scale cultural producers who hitherto, could not access certain distant markets. With digital technology, small scale CCI producers in a remote part of the globe can produce and sell their creative output to anybody anywhere in the world. But it also means that large brands now have potentially unfettered access to consumers in every nook and cranny of the globe previously served by small and local producers. This means global competition for small and local producers. This is made possible by the internet and the many networking platforms it avails. It also means that neoliberal capitalist forces, utilizing digital technologies, are now able to gather private individual information about ordinary citizens and use same to their advantage. Using this information, they employ digital recommendation systems to push consumer products and services to unsuspecting members of the public, sometimes in ways that are invasive to individual privacy.

The result of both scenarios (marketing and sale by small scale producer and by sophisticated capitalist forces) is that digital technologies promote consumerism to the benefit of capitalism. It is however argued, that digital recommendation systems create the illusion of personal freedom and choice. Whereas in fact, they curb the free agency of individuals to truly explore before choosing (Cohn, 2013). They guide the individual toward certain products and services at the expense of others, through content filtering algorithms. Some writers have argued further that these digital recommendation systems are tools used by neoliberal large capitalist corporations - Google, Amazon, eBay, Alibaba, etc. In many ways, digital recommendation systems are products of the unpaid labour of internet users who spend valuable time surfing the web and contributing to online product reviews only to provide market consumption information for others to use free of charge.

\section{Research Methodology}

The research process adopted the qualitative approach and involved the use of in-depth interviews, online observations and digital content review as qualitative data collection methods. This study combined these three methods in complementary ways, to gather sufficient data from diverse sources. Combining more than one method can offer advantages not available through the deployment of any one method alone. The units of analysis in this study consist of independent fashion designers in the city of Lagos, Nigeria. Thus, the sample consists of fashion designers who are active users of various digital media platforms for marketing communication and promotion. The study employed the purposeful sampling method. Purposeful sampling means study participants are selected because they are likely to generate useful data for the project. To improve study validity, the maximum variation approach, in which varied characteristics of the population are identified and used to establish criteria for sample unit selection, was applied. This involves identifying key demographic variables that are likely to have an impact on participants' view of the topic and ensuring that they are reflected on the sample units. 
Age as an important sample characteristic ensures the representation of different generations of fashion designers. The technology acceptance model (TAM) and other related studies suggest that age might be an important factor in the adoption of technology and social media by individuals. Although some literature on the TAM also indicate a slight gender bias towards females with respect to social media adoption, in this study, gender as a factor also ensures a measure of gender representation to the sample. A deliberate effort was made to select participants from both geographic axis of the city of Lagos - Lagos mainland and Lagos Island. This was done to ensure proper coverage of the city's diverse economic backgrounds, social perceptions and idiosyncrasies. The designers' segments of focus as a factor was also applied to ensure that participants chosen covered various market segments. Based on the identified factors, 16 fashion designers from different age brackets, gender, target business segments and doing business at various parts of Lagos, constituted the sample.

Qualitative research involves interviewing as many subjects as necessary to find out what they need to know. For most qualitative studies of this nature, 15 respondents will constitute a practical number to work with. But a useful rule is to keep interviewing and collecting data until you reach a saturation point where no new idea or insight is received from respondents. During the interview process, the researcher continued interviewing until the realization that saturation point had been reached by the 16th interview. Thus, the study involved 16 participants. The qualitative data analysis for the study was carried out in phases. It involved listening to the interview recordings, reading interview notes, observing online activities of the study participants. It also involved observing the types of content used, patterns, frequencies and other characteristics that seemed to define their communication practices. The interviews were transcribed within a few days after the date of each interview. The audio file for each interview was replayed and listened to several times, in an iterative fashion. Using Microsoft excel as software and the research questions as guiding framework of the QDA, words, phrases and sentences that signified emergent themes and salient factors were highlighted, categorized, analyzed and used to interpret what the data revealed.

\section{$5 \quad$ Results and Findings}

A summary of the study findings indicates that there are benefits and burdens associated with the use of digital media platforms. Some participating designers say that digital media can mar you just as quickly as it can make you. It can build your brand almost as quickly as it can destroy it. This makes digital media use a two-edged sword that can cut both ways. Table 1 below presents a summary of why fashion designers use DICTs for marketing and promotion. Also, some of the responses from the participating designers that showed the usefulness and challenges of digital media are quoted below:

Table 1: Two broad categories of reasons why fashion designers use digital media channels

\begin{tabular}{|l|l|}
\hline \multicolumn{2}{|c|}{ Reasons why fashion designers use digital channels } \\
\hline For operational convenience & For economic prosperity \\
\hline Ease of use & Cost-effective means of communication \\
\hline Wide audience reach & Direct sales channels \\
\hline Speed and immediacy & $\begin{array}{l}\text { Platforms for international recognition and access to } \\
\text { fashion markets }\end{array}$ \\
\hline More control over marketing activities & Provide democratic and non-discriminatory market access \\
\hline It's about photos and videos & Creates street credibility, brand traction and sales growth \\
\hline A virtual catalogue of design outputs & $\begin{array}{l}\text { Provide opportunities to gather data analytics that give } \\
\text { market insight }\end{array}$ \\
\hline $\begin{array}{l}\text { Interacting and staying connected with target } \\
\text { audience }\end{array}$ & $\begin{array}{l}\text { Provide opportunities for cross marketing and } \\
\text { collaboration }\end{array}$ \\
\hline $\begin{array}{l}\text { Helps designers staying current and keep up with } \\
\text { social trends }\end{array}$ & $\begin{array}{l}\text { Provide opportunities for the commodification of } \\
\text { audience followers }\end{array}$ \\
\hline $\begin{array}{l}\text { Provides a convenient and fast way of gathering and } \\
\text { analyzing data that give market insight }\end{array}$ & $\begin{array}{l}\text { Provides convenient platforms and opportunities for } \\
\text { collaboration and cross marketing }\end{array}$ \\
\hline
\end{tabular}


"Basically, it is to connect and sell. Because you really don't know what will happen when you post stuff online. You put-out stuff on social media and someone you don't know from anywhere request the outfit and sends you their measurement details for you to make the outfit for them. So, it's an avenue to connect, market and sell one's outputs.” (Designer 1)

"Yes, I use it as a digital catalogue, and as platform to showcase all my new designs. Practically everything I make is on Instagram. About $95 \%$ of what I do are put out. [...] Because it is my only marketing channel. [...]. I can't do anything without digital media. It is my only medium for marketing and reaching out. [...]. We make videos and share photos that tease the audience and whet their appetite. Our videos dramatize the experience of wearing the dress and our photo shows are designed to generate attention and interest." (Designer 6).

"I use my social media handles for marketing. My Instagram, Facebook and Twitter are synchronized. Once I post on Instagram, such posts also appear in my Facebook and Twitter handles. I use Pinterest when I need inspiration. It is more like a place where artists display their works. I go to draw inspiration. Occasionally, I also use Fashion blogs, especially, when I have a new collection that I want to put out there..." (Designer 10).

'It is easy to use - it's right there on my phone. I can open the app and just go through one million pictures with ease. It links you from one page to another with much ease...'(Designer 7 )

'One of the main reasons I use Instagram is that it's quick and easy to put things out there' (Designer 16).

"It is faster to be applied. It leads to sales faster than other channels and has the ability to become viral and ubiquitous. Overnight, something can become ubiquitous. Such speed and immediacy is hard to replicate in brick and mortar." (Designer 8).

"Because social media is constantly available, you can post pictures as many times as you wish in a day. When you have new designs, you can easily put them up. The frequency of use is largely unrestricted. Unlike fashion shows and magazines that are periodic and not constantly available. When you have new designs, social media gives you the opportunity to constantly engage your customers on your page, without having to wait for a fashion show or magazine. You can't engage the audience when you have new designs after the fashion show ends. You have to wait until the next season. But with social media, you can decide to do a mini collection, take pictures and share on your page and with some blogs as often as you wish." (Designer 12).

"They are cheaper to use. Marketing can be done in a broader way with less money. Exhibitions and fashion shows are really expensive to undertake.” (Designer 16).

"Digital channels open you up to a global audience of people who can buy your clothes. It is not limiting to people who are physically around you and to physical foot falls in your store." (Designer 16).

"For example, on Instagram, we had messages from Australia commending our items. In other words, we have had marketing enquiries from as far as Australia. We have sold items internationally from our Facebook posts.” (Designer 5).

"Digital media channels are not discriminatory. Everyone can use them, especially, beginners. Other channels can be expensive, and sometimes not easily accessible, especially to beginners. Apart from the fact that you find that fashion shows don't really bring you potential clients, they are essentially discriminatory - they shut out a lot of us. [...] The amount required to fund participation in a fashion show is usually more than most beginners can afford. Besides the fashion show is for those who have already built their brand through other means of publicity." (Designer 7).

According to the fashion designers, digital media use has helped expand markets, deregulated closed markets, facilitated free trade, engendered individual freedom of artistic expression, and promoted international trade. These are all sub-themes of neoliberalism and the CCI. Yet, digital media use has also created burdens of precarious work and other work-related anxieties and uncertainties. These include overworking and self-exploitation, anger and irritation over copying and unauthorized appropriation of designs and IPs, loss of revenues due to sundry factors related to digital media use, anxiety and emotional 
stress due to negative online comments which sometimes give the feeling of professional inadequacy and rejection. These burdens are inter-woven between economic and emotional issues. In some instances, the issues are more economic but have emotional impact on the designers. In other instances, they are more of emotional issues but have economic consequences embedded in them. The following remarks by some of the participating designers provide insight into some of the negative aspects of DICTs use. Some designers indicated that copying and negative online comments, among other factors are two of the negative effects of DICT use.:

"People have copied my designs when I put them out there. If someone copies your designs, it feels like an opportunity lost in terms of business. But I always say, if someone copied your design and made it (through another dressmaker), they were never your customer in the first place. If they were your customers, they will come to you. But if they had to go to someone else to do, they probably cannot afford your cost, that's why they are doing that" (Designer 11).

"From time immemorial designers have always contended with the challenge of copying. To be honest copying is not a major concern for contemporary designers today. This may have been a worry many years ago. But today, most designers know they are going to be copied, so they just get on with what you have to do. What brands do now is to strengthen the profile of the brand in a way that gives it top of the mind of fashion enthusiast so that fashion consumers will keep the brand in mind when they want to buy. [...] For instance, Chanel and Prada have always known that they will be copied, but they never dwell on it. They just get on with what they are doing." (Designer 9).

"The truth is that everyone makes mistakes. I have had clients that come here to tell me they were not happy with what they got from me. Even though these complaints are in the minority, all it takes is for one of them to speak out in social media to say, "my dress wasn't what I expected... it was a disaster... etc.". Trust me the backlash that could follow would probably hurt me" (Designer 7).

"Negative reactions to designs on social media can alter the creative mood of the designer and affect confidence levels, and make you feel like. 'I'm not doing well'." (Designer 8).

"Yes, sometimes people say absolute nonsense about the garments. Yes, negative comments definitely hurt your feelings and then you move on, that's all" (Designer 11).

"We know that negative stories and comments which go viral can be damaging to our brand, so we are extra careful what we share on social media and how we react to negative comments" (Designer 13).

In other words, the findings indicate that the use of digital media for marketing by fashion designers produces both emotional and economic distress on fashion designers. Emotional distress factors in the use of digital technologies are related to the emotional irritations felt when their designs are copied, when negative comments are posted about the designer's works, when online relationships go bad, etc. There are also potentials of economic losses due to copied designed, cybercrimes and electronic fraud, loss of staff to competitors, lost production time due to addictive and time-consuming nature of social media, etc. All of these possible outcomes of digital media use combine to create precarious conditions of work among fashion designers, despite the inherent huge benefits. Internet-based digital media use, while giving local designers access to international fashion markets, has also created the burden of giving global players in fashion access to local markets otherwise enjoyed by small-scale producers and local designers. This is reminiscent of the burden and challenges the likes of Google, Amazon, eBay, Alibaba, are posing to local small players in advertising, publishing and other segments of the creative industries. The dominance of these new global players in the economic landscape is seen as undeniable hallmark of neoliberal capitalism and globalization. Thus, digital media use may inadvertently be promoting both the positive and negative aspects of neoliberalism.

\section{Conclusions}

The use of DICTs brings benefits and burdens to fashion designers. Despite the fact that it makes it easier and faster to promote designers works, it equally makes it easier for their works to be copied. But copying 
was not a major concern for designers. Designers are more concerned about the potential risk of damage to their brand and reputation arising from customer dissatisfaction (real or imagined) expressed and escalated online. Also, the long working hours and continuous interaction with target audience which DICT platforms availed also meant fashion designers were prone to affective labour and self-exploitation. These constituted stress and anxiety factors for designers. Instagram has especially enabled small designers to promote their designs and to access distant markets. Yet, it has also made it easier for global players to access local markets otherwise reserved for local designers. In other words, it feeds you in one hand but can knock the food off with the other hand. This is synonymous with neoliberalism where free markets mean small players can enter previously exclusive markets. Yet, it also means that large global players with scale and resource advantages can out-compete small local players. In fact, the entire landscape of intellectual productions and the knowledge economy has been disrupted and permanently altered by these technologies. But despite all the issues associated with the use of DICTs, most designers affirmed that their use significantly eliminated the constraints of time and space, lowered the barriers of market entry, provided access to global pipelines of information on product innovation, process innovation, skills/material sources, etc. Hence, in many ways digital media technologies and neoliberalism are converging in the effects they are producing on the CCI. But designers and creative workers should seek ways of optimizing the benefits of using DICTs while avoiding the precarious effects.

\section{Declarations}

\subsection{Study Limitations}

Every research work has limitations. The following are some limitations of this work. Due to resource constraints, the study covered only the fashion design segment of the CCI and just 16 fashion designers. Some may consider this a small sample. The time frame of coverage (only 6 months of observation - July 2018 to December 2018) is also a limitation. Perhaps a longer period would have produced more information for analysis. As with all research and statistical data, it provides us with a snapshot of behaviour within a time frame (specific period in time). Also, the study only covers the city of Lagos, Nigeria. But the decision to study Lagos was made in recognition of the fact that, Lagos is one of the major hubs of economic activities and cultural productions such as film, music, photography, fashion designing, and others, in Nigeria. It is also important to note that trends in fashion and ICT can become obsolete very quickly. This may be a limitation in the near future. Finally, the philosophical and methodological paradigm of a researcher also creates a limitation. This is because the researcher's paradigm affects the way the study is approached and how interpretations are made, and findings reached. In this study, the pragmatic paradigm was adopted. Nevertheless, as stated earlier, measures were taken to improve the validity of the findings.

\subsection{Informed Consent}

The consent of all the study participants was sought and received at the beginning of each interview session. A signed ethical statement was read to every participant assuring them of confidentiality and giving them the freedom to answer or not answer any question asked. Based on their consent, the interviews were held, and data collected.

\subsection{Competing Interests}

The author declares that no conflict of interest exists in the publication of this work.

\section{How to Cite this Article:}

Samuel, K. (2019). Neoliberalism, Digital Communication Technologies and the Cultural and Creative Industries. Advanced Journal of Social Science, 6(1), 96-108. doi:10.21467/ajss.6.1.96-108 


\section{References}

Aaker, D.A. (2014). Aaker on branding: 20 principles that drive success. New York: Morgan James Publishing.

Abbasi, M., Vassilopoulou, P., \& Stergioulas, L. (2017). Technology roadmap for the creative industries. Creative Industries Journal, 10(1), 40 - 58. Retrieved from https://doi.org/10.1080/17510694.2016.1247627.

Adorno, T., \& Horkheimer, M. (1944). The culture industry: Enlightenment as mass deception. Retrieved from http://www.marxists.org/reference/archive/adorno/1944/culture-industry.htm.

Adorno, T., \& Horkheimer, M. (1947). Dialectic of enlightenment. In G.S. Noerr (Ed.) Dialectic of Enlightenment: Philosophical fragments. (2002) Stanford, CA: Stanford University Press.

Arvidsson, A., Malossi, G., \& Naro, S. (2010, July). Passionate work? Labour conditions in the Milan fashion industry. Journal of Cultural Research, 14(3), 295 - 309. Doi: 10.1080/14797581003791503.

Banks, M. (2007). The politics of cultural work. Basingstoke: Macmillan.

Bathelt, H., Malmberg, A., \& Maskell, P. (2004). Clusters and knowledge: Local buzz, global pipelines and the process of knowledge creation. Progress in Human Geography, 28(1), 31-56.

Bourdieu, P. (1993). The field of cultural production: Essays on art and literature. New York: Columbia University Press.

Broumas, A. (2017). The ontology of the intellectual commons. International Journal of Communication, 11, 1507- 1527. Retrieved from http://ijoc.org/index.php/ijoc/article/view/6347/1991.

Castells, M. (2000). The Rise of the Network Society. (2nd ed.). Oxford: Blackwell Publishers.

Castells, M. (Ed.). (2004). The network society. A cross-cultural perspective. Cheltenham, UK; Northampton, MA: Edward Elgar.

Caves, R.E. (2000). Creative Industries: Contracts between Art and Commerce. Cambridge, MA: Harvard University Press.

Chambers, J. (2017, Jan. 16). Economic prosperity in the digital age. Retrieved from Project Syndicate website: https://www.projectsyndicate.org/commentary/us-needs-digitization-strategy-by-john-chambers-2017-01

Cohen, N.S. (2012). Cultural work as site of struggle: Freelancers and exploitation. Triple C, 10(2), $141 \quad-155$. doi:https:doi.org/10.31269/triplec.v10i2.384. Retrieved from http://www.triple-c.at/index.php/tripleC/article/view/384

Cohn, J.A. (2013). Postfeminist technologies: Digital media and the cultural industries of choice (Unpublished doctoral dissertation, University of California, Los Angeles). Retrieved from http://escholarship.org/uc/item/3tg184z1.

de Peuter, G. (2014). Beyond the model worker: surveying a creative precariat. Culture Unbound. 6, 263 -284. Retrieved from http://www.cultureunbound.ep.liu.se

Department of Culture, Media and Sport (DCMS). (1998). Creative industries mapping document 1998, London: DCMS. Retrieved from webarchive.nationalarchives.gov.uk/+/http://www.culture.gov.uk/reference_library/publication/4740.aspx

Department of Culture, Media and Sport (DCMS). (2001). Creative industries mapping document 2001. London: DCMS. Retrieved from https://static.a-n.co.uk/wp-content/uploads/2016/12/DCMS-Creative-Industries-Mapping-Document-2001.pdf

Florida, R. (2012). The rise of the creative class-revisited: 10th anniversary edition. New York City: Basic Books.

Galloway, S., \& Dunlop, S. (2007). A critique of definitions of the cultural and creative industries in public policy. International Journal of Cultural Policy, 13(1), 17-31.

Garnham, N. (1987). Concepts of culture - public policy and the cultural industries, Cultural Studies, 1(1), 23-37.

Gill, R. (2007). Techno-bohemians or the new cybertariat? New media work in Amsterdam a decade after the web, Network Notebooks. Amsterdam: Institute of Network Cultures.

Gill, R. (2010). Life is a pitch: Managing the self in new media work. In M. Deuze (Ed.), Managing media work (pp. 249 -262). London: Sage.

Gill, R., \& Pratt, A. C. (2008). In the social factory? Immaterial labour, precariousness and cultural work. Theory, Culture \& Society, 25(78), 1-30.

Habermas, J. (1989). The Structural Transformation of the Public Sphere: An Inquiry into a Category of Bourgeois Society. Cambridge: Polity Press.

Hardt, M., \& Negri, A. (2000). Empire. Cambridge: Harvard University Press

Harvey, D. (2007). A brief history of neoliberalism (1st ed.). Oxford University Press: USA

Hesmondhalgh, D. (2002). The cultural industries. London; Thousand Oaks, CA: Sage.

Hesmondhalgh, D. (2007)). The cultural industries. (2nd ed.). London; Thousand Oaks, CA: Sage.

Kalleberg, A. (2009). Precarious work, insecure workers: employment relations in transition. American Sociological Review, 74(1), 1-22. https://doi.org/10.1177/000312240907400101.

Kalleberg, A.L \& Hewison, K. (2012). Precarious work and the challenge for Asia. American Behavioral Scientist, 57(3), 271 -288. https://doi.org/10.1177/0002764212466238.

Kotler, P. (1980). Marketing management: Analysis, planning and control. (4th ed.) Englewood Cliffs: Prentice-Hall International.

Lee, D. (2013). Creative labour in the cultural industries. Sociopedia.isa. doi: 10.1177/205684601181

Li, F. (2018). The digital transformation of business models in the creative industries: A holistic framework and emerging trends. Technovation. doi: 10.1016/j.technovation.2017.12.004. Retrieved from http://openaccess.city.ac.uk/id/eprint/18730

Lovink, G., \& Rossiter, N. (Eds.) (2007). My creativity reader: A critique of creative industries. Amsterdam: Institute of Network Cultures.

Marshall, M. N. (1996). Sampling for qualitative research. Family Practice, 13(6), 522-525. Retrieved from http://dx.doi.org/10.1093/fampra/13.6.522

McRobbie, A. (2002). From Holloway to Hollywood: Happiness at Work in the New Cultural Economy? In P. du Gay \& M. Pryke (Eds.) Cultural economy: Cultural analysis and commercial life, (pp. 97-114). London: Sage

Merges, R. P. (2004). A new dynamism in the public domain. University of Chicago Law Review, 71(1), 183-203. Retrieved from https://schorlarship.law.berkeley.edu/facpubs

Miège, B. (1989). The capitalization of cultural production. New York: International General

Negri, A. (1989). The politics of subversion: A manifesto for the twenty-first century. Cambridge: Polity Press. 
Kelechi Chijioke Samuel, Adv. J Social Sci.; Vol. 6 Issue 1, pp: 96-108, 2020

Neilson, B., \& Rossiter, N. (2005). From precarity to precariousness and back again: Labour, life and unstable networks. The Fibreculture Journal, 5. Retrieved from http://five.journal.fibreculture.org/fcj-022-from-precarity-to-precariousness-and-back-again-labour-lifeand-unstable-networks/

Oakley, K. (2006). Include us out: Economic development and social policy in the creative industries. Cultural Trends, 15(4), 255-273.

Oakley, K. (2009). Art works - cultural labour markets: A literature review. Creativity Culture and Education Series. Retrieved from www.creativitycultureeducation.org/research-impact/literature-reviews/

Patton, M.Q., \& Cochran, M. (2002). A guide to using qualitative research methodology. Paris: Medicin Sans Frontieres.

Peck, J. (2005). Struggling with the Creative Class. International Journal of Urban and Regional Research, 29(4), 740-770. https://doi.org/10.1111/j.1468-2427.2005.00620.x

Portes, A. (1997). Neoliberalism and the sociology of development: Emerging trends and unanticipated facts. Population and Development Review, 23(2), 229-259. doi:10.2307/2137545

Pratt, A. C. (2006). Cultural industries and public policy: An oxymoron? International Journal of Cultural Policy, 11(1), 31-44. Retrieved from https://doi.org/1080/10286630500067739

Pratt, A.C. (2000). New media, the new economy and new spaces. Geoforum, 31(4), 425-436. Doi: 10.1016/S0016-7185(00)00011-7. Retrieved from http;//eprints.lse.ac.uk/21388/

Pratt, A.C. (2008). Creative cities: The cultural industries and the creative class. Geografiska Annaler: Series B, Human Geography, 90(2), 107-117. https://doi.org/10.1111/j.1468-0467.2008.00281.x

Ryan, B. (1992). Making capital from culture. Berlin and New York: Walter de Gruyter.

Sapir, E. (1931). Fashion. Encyclopedia of the social sciences, 6, 139-144. New York: Macmillan. Retrieved November 2018 from https://brocku.ca/MeadProject/Sapir/Sapir_1931b.html

Schneider, F. (2002, Jul.). Size and measurement of the informal economy in 110 countries around the world. Paper presented at a workshop of Australian National Tax Centre, ANU, Canberra, Australia). Retrieved from https://www.researchgate.net/publication/253147023_Size_and_Measurement_of_the_Informal_Economy_in_110Countries_Around_the_World

Scolari, C.A. (2009). Mapping conversations about new media: the theoretical field of digital communication. New Media and Society, 11 , 943-964. Retrieved from http://nms.sagepub.com

Scott, A.J. (1999). The cultural economy: Geography and the creative field. Media, Culture and Society, $21(6), 807$ - 817. https://doi.org/10.1177/016344399021006006

Scrase, T.J. (2003). Precarious production: Globalisation and artisan labour in the third world. Third World Quarterly, 24(3), 449 - 461. Doi: $10.1080 / 0143659032000084401$

Shultz, B.J. (2011). Handmade and DIY: The cultural economy in the digital age (Unpublished doctoral dissertation). The University of Tennessee, Knoxville. Retrieved from http://trace.tennessee.edu/utk_graddiss/1025.

Spender, L. (2009). Digital culture, copyright maximalism and the challenge to copyright law (Unpublished doctoral dissertation, University of Western Sydney, Australia). Retrieved from https://researchdirect.westernsydney.edu.au/islandora/object/uws\%3A7052/

Terranova, T. (2004). Network culture: Politics for the information age. London: Pluto Press.

Tronti, M. (1966). Operai e capitale (Workers and capital). Turin: Einaudi.

ul Haque, I. (2004, July). Globalization, neoliberalism and labour. Discussion Paper No. 173 presented at the United Nations Conference on Trade and Development. Geneva, Switzerland. Retrieved from UNCTAD/OSG/DP/2004/7.

Vallas, S., \& Prener, C. (2012). Dualism, job polarization, and the social construction of precarious work. Work and Occupations, 39(4), 331353. doi: https://doi.org/10.1177/0730888412456027.

Virno, P., \& Hardt, M. (1996). Radical thought in Italy: A potential politics. Minneapolis, Minn.; London: University of Minnesota Press. von Hippel, E. (2005). Democratizing innovation. Cambridge, MA: the MIT Press.

Vosko, L. (2010). Managing margins: Gender, citizenship, and the international regulation of precarious employment. Oxford, UK: Oxford University Press.

\section{Publish your research article in AIJR journals- \\ $\checkmark \quad$ Online Submission and Tracking \\ $\checkmark$ Peer-Reviewed \\ $\checkmark$ Rapid decision \\ $\checkmark \quad$ Immediate Publication after acceptance \\ $\checkmark \quad$ Articles freely available online \\ $\checkmark \quad$ Retain full copyright of your article. \\ Submit your article at journals.aijr.in}

Publish your books with AIJR publisher-

$\checkmark \quad$ Publish with ISBN and DOI.

$\checkmark$ Publish Thesis/Dissertation as Monograph.

$\checkmark$ Publish Book Monograph.

$\checkmark$ Publish Edited Volume/ Book.

$\checkmark$ Publish Conference Proceedings

$\checkmark$ Retain full copyright of your books.

Submit your manuscript at books.aijr.org 